\title{
FAMILIAS DE EMIGRANTES NO NORTE DO PARANÁ
}

\section{Interrogações sobre uma possivel "Pastoral dos Ausentes"}

\author{
Sidnei Marco Dornelas *
}

\author{
"A gente vê uma familia formada para quê? \\ Para ficar eu e minfia esposa."
}

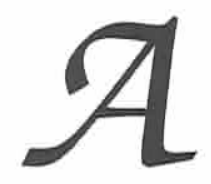

região norte do Paraná está marcada historicamente pela migração. Se no espaço de pouco mais de trinta anos ela se povoou intensamente no ritmo da expansão do café, em menos de dez anos ela conheceu um movimento extraordinário de emigração, movido pela urbanização do país, pelo avanço da fronteira agrícola em direção à Amazônia e pela sua própria modernização agrícola e concentração fundiária, que veio esvaziando, desde então, o campo paranaense. Os efeitos para a população rural e urbana se fizeram sentir, principalmente, sobre os grupos mais vulneráveis, o chamado proletariado rural. Essa história de migração influenciou de diferentes maneiras a atuação da Igreja Católica nessa região. Atualmente, as tendências que levaram a esta crescente expulsão de população continuam a agir, atingindo até mesmo a classe média urbana, e criando, a partir da última década, um grande movimento de emigração para fora do país. Trata-se de um fato novo, que traz para dentro da Igreja e da Pastoral do Migrante uma diversificação de problemas e de pessoas a serem acompanhadas, levando inclusive a se perguntar: é possível uma pastoral dos ausentes?'

\section{A REALIDADE DA MIGRAÇÃO NO NORTE DO PARANÂ}

A história da ocupação do norte do Paraná remonta à ação da Companhia de Terras Norte do Paraná (CTNP), que colonizou as terras devolutas adquiridas pela Paraná Plantations Limited, com sede em Londres. O empreendimento de colonização de uma extensa área de mais de $500 \mathrm{mil}$ alqueires em pequenos lotes de 15 alqueires permitiu que, do início dos anos 1930 até meados da década de 1950, cerca de 100 mil famílias de agricultores se instalassem na região. Esses agricultores vieram, sobretudo do interior do Estado de São Paulo, e eram em sua maioria paulistas, remanescentes da imigração européia e japoneses, além de mineiros e nordestinos. Esse imenso povoamento do norte do Paraná teve como centro a cidade de Londrina, fundada em 1929. como sede da Companhia de colonização, tornando-se rapidamente um pólo de referência urbano para as migrações no Paraná.

Outros projetos de colonização de caráter privado ou governamental se desenvolveram no norte e restante do estado do Paraná, permitindo o crescimento deste afluxo de população migrante, como os núcleos de colonização dirigida de Assai e Uraí, ocupados majoritariamente por agricultores de origem japonesa (Westphalen, Machado e Balhana, 1988, p. 16-17; ElKhalib, 1969, p. 30, 164). A maioria destes projetos de colonização se apoiava no desenvolvimento da cultura comercial do café, que além de seus proprietários, empregava uma grande quantidade de mão-de-obra na sua exploração. $\mathrm{O}$ avanço da fronteira agrícola no norte do Paraná entre os anos 1940 e 1970 resultou, desta maneira, num dos maiores fluxos migratórios da história do Brasil. As taxas médias de crescimento anuais 


\begin{tabular}{|c|c|c|c|c|}
\hline \multicolumn{5}{|c|}{ Taxas Médias Geométricas (100 hab.) } \\
\hline & $\mathbf{1 9 4 0 / 5 0}$ & $\mathbf{1 9 5 0 / 6 0}$ & $\mathbf{1 9 6 0 / 7 0}$ & $\mathbf{1 9 7 0 / 8 0}$ \\
\hline BRASIL & 2,39 & 2,99 & 2,89 & 2,49 \\
\hline PARANÁ & 5,61 & 7,16 & 4,97 & 0,97 \\
\hline
\end{tabular}

Fonte: IBGE Tabulaçōes avançadas do Censo Demográfico, 1981 (apud CEM, 1986, p. 26)

da população do Estado neste período ultrapassavam os $4.5 \%$, enquanto a média nacional não chegava aos $3 \%$ :

Ao verificar a evolução do crescimento da população do Paraná, ao longo destas quatro décadas, salta aos olhos a ruptura ocorrida nos anos 1970. A queda abrupta da taxa média de crescimento para 0,97 aponta para os impactos sociais do processo de modernização agrícola no meio rural paranaense. Com efeito, a confluência de fatores como a interferência do Estado na política de créditos agrícolas, que favorecia os grandes empresários rurais, a introdução da monocultura da soja, o uso intensivo de máquinas e implementos agrícolas, e, conseqüentemente, a concentração fundiária, apressaram a decadência da cultura do café e o enfraquecimento da pequena propriedade. Deu-se, então, um enorme movimento de esvaziamento do campo, com fluxos de migrantes orientando-se para diferentes direções. O mais significativo foi a migração ruralurbana, que se traduziu também numa migração inter-estadual, que se dirigiu para alguns dos principais centros urbanos do estado de São Paulo. Essa evasão de população coincidiu, por outro lado, com a implantação de diversos projetos de colonização nas frentes pioneiras dos estados do Mato Grosso e de Rondônia, originando então uma grande corrente migratória rural-rural. Mobilizaram-se milhares de famílias de agricultores paranaenses, que venderam suas propriedades no Paraná, buscando terras mais baratas na fronteira agrícola na Amazônia (CEM, 1986). Outros produtores de café também aproveitaram a oportunidade para se deslocar para regiões mais favoráveis à cafeicultura, nos estados de Minas Gerais e Goiás. Esses agricultores ainda se servirão da mão-de-obra sazonal de milhares de lavradores reduzidos a trabalhadores volantes nas pequenas cidades do norte do Paraná. ${ }^{2}$

$\mathrm{Na}$ verdade, o esvaziamento do campo criou também um novo quadro migratório no interior do estado do Paraná. Houve a partir deste período, nos anos 1980 e 90, uma constante migração rural-urbana que se dirigia para grandes centros, como a periferia da região metropolitana de Curitiba e os arredores de Londrina (Kleinke, Deschamps \& Moura, 2000). Apesar da dinâmica econômica desenvolvida nos centros urbanos, a indústria e o comércio não conseguiam absorver esse contingente populacional. Nas cidades do interior do estado, formouse um proletariado rural que residia nas suas periferias, e que mantinha ainda uma forte vinculação com o trabalho agrícola, embora procurando complementar sua renda com atividades informais e subempregos do meio urbano. São migrantes que passaram a se empregar crescentemente como trabalhadores temporários, na época da colheita de culturas como a da cana e do café, no interior do Paraná e em outros estados. Sua precariedade social levou, inclusive, o governo do Estado do Paraná a elaborar um projeto de "retorno" destes trabalhadores e suas famílias ao meio rural, através do Programa Vilas Rurais, implantado a partir de 1995 (Asari, Muniz \& Rosa, 2002). ${ }^{3}$

Nesse sentido, falar numa realidade migratória no norte do Paraná significava se referir ao esvaziamento da população rural, sua inserção precária nas periferias urbanas e a periódica ausência de trabalhadores sazonais que migram para diferentes regiōes do estado, e para outras regiões do país, em busca de oportunidades de trabalho. No entanto, o que vem se tornando cada vez mais perceptível nos últimos anos é a dificuldade dos centros urbanos em absorver e fornecer oportunidades de trabalho para toda essa população. Os primeiros anos do novo milênio, de uma realidade econômica de maior concorrência e flexibilidade econômica, viram também aumentar a circularidade e a instabilidade da população, também no meio urbano. Não é só a população oriunda do meio rural ou das cidades do interior, que se aglomeram nos cinturões periféricos de grandes centros como Curitiba e Londrina, que encontra dificuldades para se inserir no mercado de trabalho formal. As classes médias urbanas, que buscam manter um nível de vida adquirido ao longo de gerações, vêm também encontrando dificuldades para inserir social e economicamente as gerações mais jovens, sem incorrer numa desclassificação social.

São as classes médias urbanas de cidades como Londrina, Maringá, e 
outras do norte do Paraná, remanescentes em grande parte da imigração européia e japonesa, que se sentem atraídas pelo movimento de emigração para fora do país. Este é o fato novo da história de migração no Brasil, e que tem caracterizado também esta região. Trata-se de uma nova onda de evasão de população em busca de trabalho, de descendentes de japoneses nas fábricas do Japão, de descendentes de imigrantes europeus por empregos informais na Espanha, em Portugal, na Inglaterra, na Itália e nos Estados Unidos. ${ }^{4}$ São majoritariamente jovens, que na falta de oportunidade de ascensão social dentro do país, vão buscá-la com todos os meios possíveis, em outros continentes.

O depoimento do jovem Orestes, sobre sua decisão de migrar com a esposa para a Europa, oferece um quadro sintético das motivações e dos problemas que advém dessa escolha feita pelas novas gerações de migrantes, em cidades como Londrina:

Estava um pouco complicada a questão de emprego, há dois anos atrás, quando eu fui, para tentar construir uma casa. Demora muito tempo, a gente paga o terreno, financia, e para construir? Então, a partir dessa dificuldade, eu fui. Eu tenho um filho novo, que agora está com seis anos. Mas, quando a gente foi, ele tinha quatro anos e meio. Foi o que... infelizmente... foi preciso deixar ele. Eu e minha esposa decidimos ir para tentar uma condição de vida melhor. A gente foi atrás de trabalho fora, porque o dinheiro vale mais, e por um determinado tempo.

(...)

Como é que você vê essa siruação geral aqui em Londrina?

É uma coisa que eu estava vendo, mesmo quando estava lá, e sempre comentava com meu pai: 'está abrindo um camelódromo aqui, está abrindo uma loja aqui, está abrindo não sei o que... 'Em Londrina, eu vejo assim, tem dois tipos de miseráveis, os miseráveis que tem bastante, que não gastam, e o povo miserável que mora nos arredores e nas favelas. Então, Londrina está enfrentando uma situação bem complicada. É o país todo, é o mundo todo que está em crise. Mas, eu vejo que aqui em Londrina a questão de emprego... Eu estou preparado com os requisitos mínimos e também não consigo encontrar.

\section{Você é formado em quê??}

Eu fiz marketing e propaganda, publicidade. Fiz e fui embora, apresentei minha tese e no outro dia eu já tinha o vôo marcado.

\section{Você chegou a procurar emprego?}

Não, para mim, se fosse trabalhar, enquanto eu estava fazendo o curso, eu iria só como estagiário. Veja, um pai de família, ganhar trezentos reais, para trabalhar como estagiário, não tinha condição. Eu nem tenho experiência como estagiário, Porque, para ganhar trezentos reais, não compensava. Com trezentos reais, eu não conseguia pagar a parcela do lote que a gente financiou. Eu tenho vários amigos que se formaram, que também não estão trabalhando na área. $\mathrm{O}$ mercado não permite. É uma cidade que paga pouco. Lá, em média, os brasileiros conseguem ganhar de 500 a 600 euros.

Não é somente a realidade dos migrantes temporários que coloca questionamentos à Igreja no norte do Paraná. Os problemas da migração, gerados por uma situação econômica adversa, atingem também às famílias de classe média urbana, colocando problemas novos à pastoral. Além da questão do trabalho ilegal, da clandestinidade em outro país, do isolamento, as famílias são obrigadas a lidar com os problemas da ruptura entre pais e filhos, da educação dos adolescentes, da saúde originados pela migração, das perspectivas de futuro para quem retorna, de manter os elos familiares mesmo estando deslocados espacialmente. Os emigrantes estão presentes pela sua "ausência", questionando mesmo as modalidades de agir pastoralmente. Nessa perspectiva, a primeira questão que se coloca, seria: como é vivida esta realidade pelas famílias de emigrantes brasileiros no exterior, numa grande cidade como Londrina?

\section{AUSENTES QUE SE FAZEM PRESENTES}

Sayad nos lembra que só se pode entender a migração, se levarmos em consideração as duas polaridades que a constituem: a de que toda presença de um imigrante em um lugar, implica na ausência do emigrante em outro lugar (Sayad, 1998, p. 14-16). Nesse sentido, os depoimentos tomados entre os familiares de emigrantes brasileiros no exterior oriundos de Londrina, reforçam a percepção dessa evidência. Como acontece nos casos problemáticos, também nos bem sucedidos - em que os emigrantes, ou completaram o seu projeto migratório, reunindo as economias desejadas a fim de garantir a compra de uma casa ou estabelecer-se financeiramente, ou que se decidiram por residir no exterior, alcançando um nível de vida satisfatório - percebe-se na maioria das vezes a forte participação da família residente no Brasil na trajetória do emigrante. Ela é intensa e pode ocupar uma posição decisiva na resolução de questões que surgem da condição de clandestinidade dos parentes emigrantes nos lugares de destino.

O depoimento do pai de Orestes mostra em que medida ele pôde intervir, a partir do Brasil, para conseguir que seu outro fillho pudesse conseguir uma melhor situação, estando na Inglaterra: 
Depois de um mês, meu filho me telefonou, dizendo que "não vai dar para ficar, estamos com pouco dólar. temos que ir para escola de ônibus e o dinheiro está acabando, não sabemos o que fazer. Daí, por influência de um amigo que mora aqui $\mathrm{em}$ Londrina, obtive a informação de uma espécie de agenciador, um tal de Júlio. para ajudar a arrumar emprego para ele lá. Eu liguei daqui para lá, para esse Júlio, que morava do outro lado da Inglaterra em que meu filho se encontrava. Contei a situação e ele disse "escuta, tem emprego nessas empreiteiras, nessas fábricas, em $L$. só não tem moradia". Eu insisti, "veja ai, faça alguma coisa". Liguei três dias depois perguntando, e a resposta foi: "eu tenho uma casa aqui com mais doze morando dentro, ele aceita?". Eu disse, "aceita qualquer negócio". Ele saiu de L, e foi buscar meu filho na cidade onde estava, $400 \mathrm{Km}$. Foi lá, trouxe e jogou. Só que na casa tinha 16, e foi uma loucura. Emprego tinha, mas morar com 16 numa mesma casa, quase tudo brasileiro, na segunda semana já foi roubado (...) Para arrumar emprego, eu intercedi por ele daqui, através de amigos que conheciam esse despachante..."

Da mesma forma, o contato por telefone e Internet, tem permitido aos familiares acompanhar, às vezes em tempo real, as dificuldades e contratempos enfrentados pelos emigrantes no exterior, e mesmo ajudálos de maneira crucial. Outra estratégia que os familiares empregam para ajudar seus parentes a superar as dificuldades devidas à situação irregular em que se encontram, é procurar informações sobre antepassados, a fim de alcançar a cidadania européia, o que permitiria não só se estabelecer na Europa, mas também procurar outras formas de entrar nos Estados Unidos. O pai de Orestes mesmo buscou esta estratégia:
A gente tentou fazer umas incursões para fazer a árvore genealógica nossa lá, para ver se tem um descendente italiano por parte da minha esposa. Nesses três anos que ele ficou lá, ele ficou investigando, mas não conseguiu chegar a lugar nenhum. Mas, do lado da esposa dele, da minha nora, eu descobri na lista de leva (alistamento militar) do bisavô da minha nora. Eu dei entrada e estou com o original, depois de três anos a gente conseguiu. A minha nora, porém, não mexeu com isso. Meu filho quer ir embora, mas ela não quer. Ele depende dessa cidadania dela. Por ele, já teria arrumado e teria ido embora de novo, mas ela não quer, então criou uma situação...

Em todos os casos, a família vive intensamente a problemática de ir ou voltar, bem como as conseqüências das decisões tomadas. Nesse sentido, Albano cita o caso de uma cunhada sua que vive a angústia de seus filhos, clandestinos na Itália, com seus processos de reconhecimento de cidadania parados, sem poder voltar $\mathrm{e}$ nem rever as crianças que deixaram no Brasil:

Tenho um sobrinho que está em Trento, com seu processo de reconhecimento de cidadania parado num orgão do governo italiano. Porque Trento, na época, não pertencia à Itália, mas à Áustria. Eles estão tentando essa cidadania e não estão conseguindo. Este órgão vai analisar para ver se aprova ou não aprova. Minha cunhada mandou os filhos para Itália e eles ficaram dois anos lá, e não conseguiram, só porque essa cidade não pertencia à Itália na época. Veja a situação da minha cunhada: os dois meninos estão lá, um está casado e com a esposa. Ela está desesperada porque esse documento nāo sai e as crianças estão aqui. Quem está cuidando é a avó, e os filhos estão lá.

A tua cunhada, a avó das crianças como é que ela faz, ela consegue se virar?
Elas ficam com a minha cunhada e no final de semana vem aqui para o centro com a outra avó, são as duas avós que estão cuidando. A gente pergunta para as crianças, e a tua mãe? Ela responde a minha mãe está trabalhando, ela está lá na Itália, lá em Londres, ela está trabalhando.

Nas estratégias das famílias para levar à frente o seu projeto migratório, vários arranjos são usados para se poder dar conta do cuidados dos fillhos menores, bem como dos mais idosos. Existe o caso de Luciana, que conheceu seu marido no Japão. De retorno ao Brasil com a filha, depois de experimentar deixá-la com parentes, assumiu a responsabilidade de cuidar desta, estando grávida de outro filho, ao mesmo tempo em que cuida também dos pais de seu esposo. enquanto ele continua a trabalhar no Japão. Difícil também foi a experiência de Orestes, obrigado a retornar da Europa devido ao adoecimento de seu filho, que estava sob a guarda do avô. É este quem relata:

Quando o pai foi embora, ele tinha quatro anos e meio. Ele foi até o aeroporto e nem deu bola. praticamente não sentiu, não chorou, não reclamou do pai e da mãe. Mas, a partir de um ano e pouco, a partir de janeiro pra cá. ele começou a reclamar, eu quero meu pai, eu quero minha mâe, sonhava... Acordava, e queria o pai e a mãe. Chegou a emagrecer, emagreceu muito. A gente começou a correr atrás de assistência. Eu sou funcionário público e o coloquei no meu convênio médico. Levamos no neurologista, no pediatra. O pediatra falou: "realmente, ele emagreceu, vocês arrumem um animal ou alguma coisa assim para ele". Então, a gente arrumou um cachorrinho. Ele brincou e melhorou um pouco, mas ele telefonava pedindo, eu quero meu pai, eu quero minha mãe. Nessas épocas assim, o dia dos pais e o dia das mães, ele... até o último presente do dia das mães, ele não tinha 
a mãe para entregar e ele deu para a avó. Ficou uma coisa esquisita.

Problemas de saúde provocados pela migração são suportados pelas famílias que ficam, sejam aqueles dos filhos dos migrantes, sejam os de seus parentes próximos, que convivem mal com o sentimento de perda. Joaquina relembra a depressão por que passou, ao perceber que seu filho não mais retornaria do Japão:

Ele já veio três vezes aqui para o Brasil. Ele veio a primeira vez trazer o netinho, para eu conhecer. Depois ele veio uma segunda vez, trazer a menina. E agora ele veio, faz dois anos, porque eu fiquei doente. Fiquei com uma depressão muito forte, muita saudade, demais da conta. Fiquei muito ruim mesmo, e aí ele veio, já faz dois anos. Então, você vê que situação: eu só tenho um fillho, e esse filho está para lá, e ele não está querendo voltar. Ele não sente falta, assim, da gente conversar.

Diferentemente dos emigrantes de descendência européia, que se dirigem preferencialmente para os Estados Unidos e a Europa, os familiares dos dekasseguis (emigrantes de descendência japonesa, que vão ao Japão para trabalhar) parecem não enfrentar problemas como o da clandestinidade ou da busca de trabalho, devido ao tipo de migração que caracteriza o fluxo para o Japão. De um lado, os trabalhadores são arregimentados por empreiteiras legalizadas e existe uma legislação própria para o trabalhador dekassegui que se emprega nas fábricas japonesas. Por outro, existem aspectos étnicos que têm ressonância no modo como as próprias famílias percebem essa migração de seus parentes para o Japão. No entanto, eles também vivenciam intensamente as mudanças que a realidade da migração introduziu no interior de suas famílias. Talvez pelo caráter específico da educação familiar, reservada e rígida, em que existe um grande peso da autoridade dos mais velhos, em particular da figura do pai, existe um certo melindre em se abordar essas questões. Se os europeus - descendentes de italianos, espanhóis, portugueses - expõem mais abertamente suas frustrações, as famílias de dekasseguis, vivendo às vezes situações dramáticas, colocam seriamente a questão do "foro íntimo" em relação aos seus "ausentes presentes" da migração. No grupo nipo-brasileiro, este caráter próprio da cultura de origem japonesa foi expresso nos seguintes termos:

Na minha opinião, os japoneses são mais frios, assim, em termos de afetividade. Então, eu acho, por exemplo, que a mãe que tem um fillho lá no Japão, cla não sente como os brasileiros...

Essa primeira geração dos que vieram, nossos pais, eles eram muito honestos, esforçados. Mas, pra você ter amizade com eles, demorava muito tempo, mas quando pegava amizade, era amizade certa...

Tem muitas mães que licam aqui no Brasil, e os filhos estão lá, elas têm tristezas, mas elas não chegam para a gente e fala. Eu conheci uma senhora que ela faleceu de tanta tristeza. Os filhos foram todos embora, e aí ela morreu de tristeza, mas ela não se abria porque foram criados assim. Só entre eles ali. Não tem aquela amizade, não tem diálogo com uma pessoa para poder conversar, não se abre. Então, aquela tristeza vai tomando conta e ela acabou morrendo.

Esse lado discreto também é mostrado por Olavo, ao falar de suas dificuldades em tentar fazer algo, como advogado, pelos dekasseguis que enfrentavam problemas na migração: "achei que alguma coisa tinha que ser feita, mas a gente tem aquela questão de que tem que ser... a gente tem aquela educação assim... que o japonês, ele não entra numa briga, se for preciso ele perde, mas cle não entra." Nesse sentido, ele também acentua que a maioria dos problemas dos dekasseguis não diz respeito a questões legais ou trabalhistas, ou ainda quanto à forma de arregimentação para o trabalho. As questões que mais preocupam são aquelas que dizem respeito aos casamentos desfeitos, aos filhos que se encontram desamparados, aos problemas de saúde mental ou de delinquiência juvenil, às famílias que vivem fraturadas pelo deslocamento entre o Brasil e o Japão. As condições em que vivem os migrantes no Japão, submetidos a um regime de trabalho conhecido como KKK (sujo, pesado e estafante), vem esgarçando as relações familiares, prejudicando a educação dos jovens e criando problemas que se refletem nas angústias e nos encargos assumidos pelos membros da família residentes no Brasil (Sasaki, 2006; Arakaki, 2007; Nakagawa, 2007). Olavo expõe sua visão dos problemas dos dekasseguis:

Nesse período, na época em que eu fiz o curso de direito, achei muito estranho porque, de repente, no Fórum de Londrina, comecei a ver divórcios. separação de descendentes de japoneses. Porque, a gente, não estava habituado com isso, com a separação de casais, já com fillhos, com dois, três filhos. Casais de que se falava, "nossa que casal perfeito", e voltava e fazia separação.

Um casal se conhece lá, em uma semana está morando junto. A pessoa nem sabe quem é. Então, o que começou a acontecer? Começou a acontecer que pessoas se engravidavam, lá assim. prematuramente, porque mal conheciam a outra pessoa. Eu tenho vários casos aqui em Londrina. de familiares aqui, que a esposa está lá no Mato Grosso, está com um nenê para o lado de lá, os pais daqui não conhecem, e ele está no Japão... 
Elas deixam criança com a avó. É uma realidade, a criança fica com a avó e vai o casal, para ajuntar o dinheiro mais rápido. Porque só o marido ou só a mulher? A mulher nāo ganha muito, o salário é menor, então se juntam os dois, e vão os dois para lá. Mandam uma pensão em dinheiro para a avó. $\mathrm{O}$ que a gente notou? A criança vai crescendo e ela não consegue ver a mãe como mãe. Ela vê a avó como mãe. Quando a mãe volta do Japão, é preciso fazer um trabalho com psicólogo. psiquiatra e nas escolas, porque há uma dificuldade. Mas, as pessoas vêem só esse lado financeiro, realmente.

Porém, em todos os casos, e principalmente entre os descendentes de japoneses, são problemas que são vividos no foro íntimo da família, como algo reservado e difícil de ser verbalizado, em relação aos que estão distantes, visíveis e audíveis apenas pelos instrumentos de comunicação. mas efetivamente ausentes. Todos vivem intensamente no nível da subjetividade esses problemas. Como trabalhar pastoralmente questões que dizem respeito àqueles que não estão presentes? Ou como lidar com as sequielas presentes desta ausência? Como pode a pastoral, que sempre privilegia a presença concreta, das pessoas e seus problemas, na comunidade, lidar com estas marcas deixadas naqueles que ficaram, vividas no nível da subjetividade?

\section{UMA PASTORAL PARA AS FAMÍLIAS DOS EMIGRANTES?}

A Pastoral do Migrante no norte do Paraná se formou na busca de acompanhar o avanço da fronteira agrícola e seus núcleos de povoação. A sensibilidade da Igreja Católica por essa população migrante se fez sentir. principalmente, pela atuação da
Congregação dos Missionários de São Carlos (Scalabrinianos). A partir da fundação da Diocese de Londrina, em 1957, foram confiadas aos missionários scalabrinianos, várias paróquias que estavam sendo formadas, devido a essa onda migratória: Lobato, Flórida, Munhoz de Melo, Astorga, Iguaraçu, Ângulo, Santa Fé, além de duas paróquias na própria cidade de Londrina. Este empenho em assumir tantas paróquias indica o entusiasmo e a percepção destes missionários quanto à importância do trabalho pastoral a ser realizado nessas novas comunidades de migrantes. Outro sinal do valor atribuído a esta presença missionária, foi o investimento na construção de um grande Seminário Menor na cidade de Astorga, a partir de 1964. Todo esse esforço se apoiava em um modelo tradicional de pastoral, através de paróquias rurais com seus movimentos apostólicos: apostava-se que seriam comunidades de pequenos agricultores, estáveis ao longo das gerações, como aconteceu com as comunidades rurais de imigrantes europeus no Rio Grande do Sul. No entanto, o rápido movimento de esvaziamento dessa população rural a partir do fím da década de 1960, levou a Congregação a concluir que o movimento migratório tomava outros rumos e, por isso, julgou-se melhor entregar essas paróquias aos cuidados de suas respectivas dioceses, inclusive fechando o Seminário, depois de cerca de 20 anos de funcionamento. No final dos anos 1980, os missionários scalabrinianos concentravam sua presença numa única paróquia, Nossa Senhora Aparecida, na cidade de Londrina (Azzi, 2000, p. 154-195).

Com o fluxo de migrantes para as fronteiras agrícolas da Amazônia ou para os grandes centros urbanos, a realidade migratória do norte do
Paraná mudava radicalmente. A partir dos anos 1980, ela era caracterizada sobretudo por um proletariado rural residindo nas periferias das pequenas cidades, deslocando-se pelo Estado ou para outras regiões do país, em busca de ofertas de trabalho temporário, sobretudo na colheita do café. Como forma de dar uma resposta a essa nova realidade, constituiu-se na Paróquia Nossa Senhora Aparecida, a partir de 1991, o Centro Pastoral dos Migrantes com o objetivo de dar acompanhamento pastoral a esses migrantes temporários. Embora seja uma região de origem, ou seja, marcada pela sua ausência periódica e sazonal, o método empregado foi basicamente o mesmo usado em outras regiões receptoras de migrantes, em que se desenvolveu uma pastoral de migrantes sazonais (Equipe Pastoral dos Migrantes Dobrada/ Santa Ernestina, 1988). Os contatos com os migrantes se faziam nos seus lugares de destino, nas fazendas de café em Minas Gerais e Goiás, para depois, com as informações sobre suas localidades de origem, desenvolver uma atividade de visitas missionárias e formação de grupos de migrantes nas paróquias das pequenas cidades no norte do Paraná. ${ }^{5}$ Leocádia, agente pastoral leiga, fala dessa atividade:

Devia ser uns sessenta grupos. Aqui em Londrina tinham só alguns. Os outros estavam fora. Em toda cidadezinha do Paraná em que a gente ia, tinha. Inclusive temos a listagem aí. de todos os coordenadores, de todos os grupos da pastoral do migrante. Cada cidade tinha o seu. A gente ia, fazia reunião, celebrava, a gente ia visitar e não parava mesmo (...) Eles trabalhavam, cada grupo trabalhava na sua região, e mandavam mensalmente um roteiro dizendo: fizemos isso, isso... isso os sazonais e temporários, e nós íamos lá fazer a visita. em Minas Gerais fomos várias vezes, São Paulo, para os 
lados de Garça (...) A gente ia visitar lá onde eles estavam trabalhando, no café e nos alojamentos, e celebrava com eles lá. Quando eles voltavam, entâo íamos ao lugar de origem, andávamos pelo Paraná todo, trabalhávamos às vezes uma semana fazendo missão, fazendo missão com eles.

Esse é um modelo de pastoral que ainda caracteriza o Centro Pastoral do Migrante instalado na Paróquia, hoje Santuário Nossa Senhora Aparecida". Por esse modelo, a Pastoral do Migrante se alinhava com as outras pastorais sociais, com o trabalho desenvolvido pela Comissão Pastoral da Terra (CPT), pelo Serviço Pastoral dos Migrantes (SPM) e outros movimentos sociais. Tratava-se de um trabalho pastoral marcado pela visibilidade, pela presença nas comunidades, pela organização popular em vista da luta por direitos sociais, reivindicados perante o Poder Público. Os voluntários ligados ao Centro Pastoral percebem bem como essa linha de atuação cria uma indisposição com outros freqüentadores da Paróquia, pessoas de classe média urbana, que buscam a Igreja com uma motivação estritamente religiosa. Olavo explicita bem essa situação:

A pastoral do migrante sempre foi uma pastoral difícil, com pouca gente. É uma pastoral que é vista com um olho assim de (éo pessoal dos sem-terra: MST) E querendo, ou não querendo... É uma opinião particular: aqui na região de Londrina, a gente sente que a pastoral do migrante, ela na verdade... aqui é comerciante, é pessoal estabilizado, é um pessoal assim que não vê com bons olhos essa situação.

No entanto, no princípio dos anos 2000, a percepção da ocorrência de um grande número de pessoas que partiam para o exterior, e de famílias que sentiam diretamente as conseqüencias dessa migração, levou os membros do Centro Pastoral, com os padres da paróquia, a lançarem as primeiras iniciativas no sentido de dar uma resposta a essa realidade da emigração na cidade de Londrina. Por iniciativa do padre e um grupo de leigos de origem japonesa, foi criado um grupo nipo-brasileiro, no sentido de criar um espaço de partilha e integração entre participantes da Igreja que tinham uma mesma fé, um passado comum (imigração e cultura nipo-brasileira) e com freqüência viviam a problemática, pessoal e familiar, do fenômeno dekassegui. ${ }^{7}$ Outra iniciativa foi uma missa mensal, em que se celebraria a realidade da migração das famílias da paróquia, seguido de um momento de convivência. Leocádia explicita os objetivos dessa iniciativa:

Logo que nós começamos essa missa, a gente fazia uma recepção no salão depois da missa. Entāo, em todo quarto domingo, a gente pedia para a comunidade "quem podia trazer um prato", e a gente fazia. Aí fizemos um mês, fizemos dois, fizemos três, o pessoal comia e ia embora. Não é isso! E a parte espiritual onde fica? Aí eu falei para ele, "padre vamos parar com isso", porque, em todo quarto domingo, a gente pede para o pessoal trazer as coisas, para a gente fazer partilha, tudo bem, é bonito, é legal. é bom, mas e o outro lado? (...) ser uma missa diferenciada, năo uma missa comum. $\mathrm{Na}$ liturgia, fazer uma coisa diferenciada, para eles, direcionada para eles. Porque, se eles vem e é igual, se eles não vão se sentir estimulados. é igual. Então, vão assistir em qualquer lugar, é igual. O que eu vou fazer lá?

Essa busca em fazer algo diferenciado, junto com a dificuldade em manter o objetivo e a motivação desta iniciativa pastoral, pode ser associada também à idéia (nunca colocada em prática) de se colocar à disposição um horário da semana, em que as pessoas pudessem vir ao Centro ou à Igreja, para conversar, desabafar, encontrar orientação. Na verdade, essas propostas parecem deparar-se com o obstáculo do caráter dos problemas enfrentados por essas famílias, que se reportam ao foro íntimo familiar, à subjetividade de cada um, bem como à situação de clandestinidade em que se encontram esses migrantes, ou às marcas de uma ausência que perdura como angústia e sofrimento, num vazio que não pode ser preenchido por nenhuma prática pastoral convencional. Assim, as sugestões dadas nos depoimentos. quando se perguntou aos entrevistados sobre o que a Pastoral poderia fazer por eles e por seus parentes no exterior, foram todas no sentido de permitir desabafar, acolher o angustiado, criar a possibilidade de fazer um elo de comunicação com aqueles que estão longe, e quando muito, como ação concreta, preparar aqueles que vão viajar e ajudar a alcançar a dupla cidadania, a fim de se obter a regularização. Os familiares que ficam querem apoio para a sua sensação de perda e impotência: "o único jeito é rezar e pedir que eles vão bem lâ", como disse uma entrevistada, ou conversar, como disse Veridiana, ao lembrar como os padres antigamente estavam mais disponíveis para escutar os problemas das famílias:

Eu acho que tinha que acolher. conversar, se tivesse como conversar... É difícil porque, como a igreja faz pra acolher todo mundo e ajudar? Fica difícil... Eu nunca cheguei no padre para contar sobre o meu filho, que vai fazer um ano que está lá. Os padres nossos conhecidos, o que está lá, a gente conhece, mas não se sente em chegar e conversar, porque não são daqui. Mas, os padres antes conheciam, sabia o meu sofrimento todo, mas só que... com o meu marido. acontecia isso, sabe o que eu fazia? Eu 
vinha aqui na V., eu ia na Catedral, eu ia no Colégio das irmãs, eu ia lá e a gente conversava. Tinham os padres que conheciam meu marido, e ele ia até nas igrejas para conversar. (...) Então a gente conversava, mas é difícil, como que faz? Se para família é difícil, agora, como que faz? Só se tivesse como conversar, seria bom. As pessoas se sentem melhor conversando, como a gente está conversando.

A atilude elementar de poder conversar, de chegar em alguém próximo da família, algo tão comum quando os padres antigamente acompanhavam vilarejos, bairros e comunidades rurais, é basicamente o que se busca. Sair do foro íntimo para recuperar o elo mínimo da comunidade, entre aqueles cuja distância e o tempo da migração vem esgarçando os laços de sociabilidade. A expressão da subjetividade ferida pelas perdas, sobrecarregada pelos encargos e paradoxos da ausência, é um dos campos próprios em que se manifesta a necessidade da religiosidade. Mas, parece que as atividades da pastoral ainda estão procurando o melhor caminho para suprir essa demanda de famílias que são atingidas pela migração.

Olavo percebe a dimensão social da migração, ao comparar o movimento dekassegui com a migração sazonal que atinge trabalhadores nordestinos que vêm para o Sudeste, ou trabalhadores do Paraná que vão colher café em Minas Gerais. Porém, ele também percebe a dificuldade em estender esse tipo de acompanhamento para os emigrantes fora do país e suas famílias, mesmo considerando uma maior visibilidade da pastoral no âmbito das outras pastorais da paróquia:

Eu fui para o Japão. Fiquei um ano lá, e realmente a gente nota assim que o migrante não muda muito. O internacional que vai para o Japão. Estados Unidos, Itália, ou o que vem lá do Nordeste para cortar cana aqui, ou o que vai para Minas Gerais no café. Então, ele não muda muito. Ele sai da região dele, no caso saiu de Londrina, onde tinha toda a estrutura dele, a vida dele e vai para um lugar distante, que muitas vezes não sabe como é que funcionam as coisas lá. Ele só tem uma coisa na cabeça: trabalhar.

Sc houvesse essa visão, haveria na verdade um crescimento da pastoral, e não olhando apenas em termos de... essa questão do sem-terra, MST, do cortador de cana. Haveria uma expansão maior que atingiria não só o que vai para o Japão, mas principalmente o pessoal que vai pra Inglaterra, Estados Unidos. Então, a abrangência seria maior. As pessoas olhariam realmente... porque, infelizmente, eu vejo que as pessoas quando, se dá um status maior para qualquer situação, elas percebem e vão participar. É uma coisa simples mas você tem a camiseta da pastoral, foi na missa, é um evento da pastoral (...) Se começar a mencionar, "a pastoral do migrante, eles estão em contato com o migrante que vai para o exterior; Estados Unidos, Itália, Inglaterra. Japão", aí as pessoas vão se interessar realmente, porque a gente tem um estigma muito grande. Eu sinto essa dificuldade, porque já no ano passado eu até comentei sobre essa questão, entrei e estou aqui, a gente talvez tivesse que fazer mais, mas a gente vai na medida que dá. A gente nota que quando a gente fala, nisso eu não mexo, nisso eu não mexo... vai ser muito difícil..

Assim também, diante da proposta de um grupo de apoio, em que ele poderia atuar usando também seus conhecimentos de advogado, para as pessoas poderem desabafar, tratar seus problemas enquanto migração familiar, sua reação foi só, "mas é muito reservado",

\section{APÊNDICE}

NORTE DO PARANÁ, UMA HISTÓRIA DE PERDAS

Tocar no assunto da necessidade de seus filhos partirem para fora do país em busca de trabalho, para seus pais, é como revolver uma enorme frustração. Num ano considerado dos mais bem sucedidos do Governo Lula, o pai de Orestes expressa um sentimento que lembra muito as motivações de brasileiros que partiam para os Estados Unidos em meados dos anos 1980, chamada de a "década perdida" (Sales, 1995). Ele desabafa:

Como é que vocês convivem com essa situaçāo?

Com tristeza. Tem hora que eu falo, sinceramente eu tenho vergonha de ser brasileiro. Por incrível que pareça, moro aqui, e aqui nós não temos terremoto, furacão, vulcão, nem maremoto, mas eu tenho medo do que vai acontecer. Por outro lado, porque os filhos... eu tenho dois, os dois estão desempregados, eu não sei o que vai acontecer daqui para frente e não vejo melhoria, não vejo perspectiva nenhuma no país. Se eu pudesse... Estou com trinta e cinco anos contribuídos, mas não tenho idade, estou com 54 anos, vou me aposentar em 2011, com 37 ou 38 anos de contribuição e 58 de idade. Quando eu me aposentar, se eles falarem, vamos embora, eu vou, porque eu não vejo perspectiva nenhuma de melhora nesse país. É triste. Eu vejo isso com muita tristeza, com muita mágoa. A gente está aqui e ver os dois filhos que eu tenho, todos os dois desempregados. todas as famílias que a gente conhece, todas as que a gente se relaciona, no mínimo tem uma ou duas pessoas desempregadas, ou está fora do país. Dá uma tristeza muito grande de morar num país desses, que não provê as necessidades básicas de seus filhos. 
Essa frustração se soma à percepção que eles sentem de perda familiar, evocando momentos do passado em que outros imigrantes, vivenciaram situações similares. No grupo Nipo-brasileiro foram evocadas situações como essa:

Meu sogro deixou uma filha no Japão, e ele nunca pode ver a fillha. Porque, lá falavam assim, quando os imigrantes vieram, que no Brasil se juntava dinheiro de rastelo. Então, ele veio nessa esperança de juntar o dinheiro e voltar, e não voltou mais, não teve condiçōes. Ele adoeceu, e daí uns anos a minha sogra foi e encontrou a filha. Só que a filha não tinha amor pela mãe e pelo pai. Então, ela nem ficou na casa da filha, ela ficou na casa de um cunhado que era irmão do meu sogro. Ela ficou lá, porque foi esse cunhado dela que criou essa menina, quando eles a deixaram lá. Então, não tinha laços nenhum, e ela voltou muito triste. Ela não encontrou uma filha, então ele morreu com essa tristeza. Escrevia para as irmãs, mantinha uma correspondência. Aí a caçula da casa - porque todos seus filhos foram para o Japão - ela foi e passou um bom tempo lá, e foi visitar a irmã. Diz que foi uma festa, fizeram uma festa, receberam tão bem e ela gostou muito. Já com a mãe teve esse problema, e ela morreu com esse problema, essa tristeza.

Histórias como essa não deixam de ser associadas com certas experiências que os pais e mães dos emigrantes brasileiros vivenciam atualmente. Joaquina realiza essa associação:

A gente se preparou nesses quatorze anos, assim, financeiramente, para que, se ele voltasse para o Brasil, para ele poder viver sem aquela preocupação de estar trabalhando muito. Para poder viver com uma tranquiilidade financeira. Mas, eles querem sempre mais, mais. E quando chegam aqui, eles não tem um parâmetro para poder segurar... E não é só ele, de viver com mais modéstia. Parece que o dinheiro é tudo. Então, fica uma coisa estranha. Quando ele veio aqui, às vezes que ele veio, eu falei para ele: "você veio só pra... a tua cabeça ficou lá", eu falei para ele. Ele vem aqui mas fica pensando lá. (marido: vem aqui e fica pensando lá... quem está lá pensa aqui, quem está aqui pensa lá) Eu já vim de uma família que meus pais eram migrantes, meu pai $\mathrm{e}$ minha mãe. Eles são espanhóis, só que eles vieram crianças. Mas, eu sempre ouvi aquela história que meu avô, o pai de minha mãe, quando ele veio, ele era casado pela segunda vez. Naquele tempo, lá na Espanha, não é como hoje, que o pessoal telefona, é computador, é viagem. Então, ele veio e deixou uma filha lá, que nunca mais ele viu. Ele faleceu aqui no Brasil e nunca mais viu aquela filha, com quem depois eu que tive contato. Então, a gente já vem de uma experiência, e quando você pensa que está assim tranqüila, você perde. Eu sempre falo, como meus avós sofreram, sofreram também quem ficou lá. Depois, uma tia minha voltou para a Espanha, e ela trouxe uma foto, como a terra do meu pai e da minha avó foi tombada como patrimônio histórico, naquela rua tinha uma casa, que tinha uma janela. E minha tia falou para mim "olha. Teresa nessa janela, o pessoal lá na Espanha fala que todos os dias a tua bisavó chorava de saudade do teu pai que estava aqui, dos parentes que vieram", isso recentemente, então é triste porque...

Você sente que nem essa senhora que chorava na janela?

Era minha bisavó, que chorava pela vinda do meu avô e do meu pai.

E você ficou doente por causa disso? Eu fiquei muito triste, porque vai chegando uma certa época assim, eu olho os rapazes nas ruas, eu vejo as crianças, a gente pensa sem querer.

Albano faz a mais eloqüente evocação dessa história familiar de migração, em que se associam às perdas e sacrifícios do passado, a frustração vivida no momento presente, ao ver os filhos partirem, se sacrificarem na clandestinidade em um país estrangeiro, e não poderem ver a família finalmente reunida:

Meu avô chegou aqui no Brasil com dezesseis anos, e veio pra região de Araraquara. São Paulo. Aí ele passou um tempo nas lavouras de café, onde ele conheceu a minha avó Teresa e casou com ela lá em Araraquara. Depois de uns dois anos, eu não sei o que deu na cabeça dele, ele resolveu achar que o Brasil não dava certo, e foi para a Argentina. Só que quando ele foi para Argentina, ele já tinha duas crianças pequenas, que era um tio meu, o mais velho, chamado Paolo, e uma irmã do meu pai, que se chamava Nicoletta. Quando eles foram para Argentina, os meninos não se acostumaram, porque lá parece que a alimentação é um pouco diferente da nossa aqui, lá não tem o arroz e o feijão, não existia pelo menos na época. A minha avó estava me dizendo que chegou num ponto em que ela falou: “ou nós voltamos para o Brasil ou nós voltamos para Itália, aqui nós não podemos ficar; porque o nosso fillho vai morrer aqui, eles não querem comer". Aí, até contando assim, a gente chega a arrepiar, porque eles vieram só com o dinheiro no bolso praticamente, da Argentina para cá. Tornaram a descer em Santos. Tinha uns Calabreses que tinham um hotel ali em São Paulo, se não me engano era o Saturno, uma coisa assim, e meu avô foi lá para comprar a comida. E na época ele năo tinha o dinheiro completo para comprar toda a comida. Então, o que ele fez? Ele comprou um prato de comida para minha avó e um para cada menino. $\mathrm{O}$ dono desse hotel, que depois passou a ser muito amigo dele, ele falou assim: "não seu Giovanni. o senhor vai comer também, eu vou te dar um prato de comida". Por isso que eu falo, a vida do imigrante não é fácil. Eu tenho uma base pelo meu filho, quando ele foi para lá, agora. Puxa vida, o desespero, porque o cara saiu no final de julho daqui, e no dia 11 de setembro caiu o avião no prédio lá. Foi difícil e até 
minha nora no primeiro embarque, que saiu daqui para lá, ela falava assim pra mim: "pôxa, seu filho é cabeçudo, ele decidiu e disse que vai e vai e eu não estava querendo ir: estou deixando minha mãe e meu pai aqui o eston deixando um fillho pra ir pra lá...". E esse meu fillho é formado veterinário, trabalhava no Estado, só para o senhor ter uma idéia: o que o meu fillho, ele e a mulher ganham num dia, ele não ganhava num mês aqui no Brasil. (...) $\mathrm{O}$ filho de um pobre, de um imigrante, de uma pessoa do interior, ele vai lá fazer um concurso, ele não passa. Mas, o filho de um "não sei das quantas". dos bons da boca lá e tal, eles encaminham o filho, encaminha o neto, bisneto, tataraneto e vai tudo... Todos eles vão pegando o seu quinhão. Então é difícil para a gente, o senhor não sabe o que passei, ficar sem dormir, preocupado, ligava para saber como é que estava... porque ele estava lá ilegal, hoje eu estou mandando o caçula meu que é formado em direito...

De Araraquara, em 39, eles vieram para Marialva, para a lavoura de café. Eles chegaram em Marialva, na época os mosquitos mordiam assim, que virava um cascão na perna, e a onça vinha pegar os bezerros e os burros dentro da mangueira. Aí eles voltaram para Rolândia e ficaram numa indústria que existia em Rolândia, onde trabalharam três anos. Em 1941 eles voltaram para lá de novo, não foi fácil. Para chegar lá na propriedade, de Mandaguari para lá, eles foram fazendo picada para o caminhão poder passar. Mandaguari, só pro senhor ter uma idéia, quando eu nasci em Marialva, em 1942, o meu pai demorou quinze dias para chegar em Rolândia para me registrar. Quando eu converso com meus parentes, eu sempre falo, que meus parentes deviam ser descendentes de cigano, porque fazer o que eles fizeram, da maneira que fizeram e andaram, para você raciocinar assim é difícil. Quando eles vieram de São Paulo pra cá, eles ficaram quinze dias na Serra Morena com o caminhão atolado no barro.
Chovia de dia e de noite, e meu pai passou por tudo isso aí. Saía lá de São Sebastião das Amoreiras e vinha a pé no barro, depois pegava um ônibus velho e vinha até Assaí, de Assaí pegava outro ônibus e vinha até Jataizinho. Saía de lá de madrugada e pegava um trem aqui às cinco horas da tarde para Cerqueira Cezar, e chegava lá às três horas da manhã. Daí andava mais três quilômetros a pé, para ir na casa do meu avô. Eles chegavam tudo queimado porque o trem era tocado a lenha, aquilo soltava aquelas faíscas e eles chegavam com a roupa toda queimada. Daí meu pai se casou, a namorada dele morava lá, mas o pai dela mudou-se e ele teve que vir pra cá. Meu pai trabalhava em Sorocabana. abandonou o serviço e veio pra cá. Sofreu que nem doido e nunca conseguiu ganhar nada. A bem dizer, $\mathrm{e}$ a gente era tudo pequeno. Quando um filho ficava doente, pegava um cavalo para levar ao médico, andava dezoito ou vinte quilômetros a cavalo, no meio do mato e foi essa vida dura.

A minha família, no início, foi para Marialva, depois foi para Rolândia e depois voltou para Marialva. Depois de alguns anos, que eles fizeram a derrubada e plantaram o café, o café estava a coisa mais linda, aí deu uma geada... ( $\mathrm{em} \mathrm{75?)} \mathrm{Não,} \mathrm{foi} \mathrm{antes} \mathrm{em}$ 46 ou 47 por aí. Meu avô se desesperou. Ele tinha construído um terreiro de café. Era coisa de louco, muito grande. Aí meu avô comprou uma fazendinha aqui, em Caixa de São Pedro. É uma cidadezinha aqui perto. e a gente morou um tempo. Depois de uns quinze anos se juntaram todos os filhos, e ele comprou cinco alqueires pra cada filho, numa cidadezinha perto de Paranavaí. E foi assim até meu avô falecer, porque ele sempre foi assim. com aquele jeito de italiano de segurar todo mundo junto. Os genros quiseram a parte em dinheiro, ele deu o dinheiro e aos filhos ele deu cinco alqueires cada um. A gente morou um tempo lá, aí meu avô faleceu, só sobrou minha avó, um vendeu, outro vendeu e foram saindo, Um veio para Maringá, nós viemos para Londrina e os outros dois ficaram lá até... foram sepultados lá mesmo, os irmāos do meu pai. E de todos esses irmãos, que eram quatorze filhos vivos na época, hoje tem só uma irmã do meu pai viva e está morando em Cuiabá. E da parte da minha mãe. só existe a minha mãe que está com 86 anos. Eu vi o sofrimento do meu pai, eu falava assim pra ele: "vamos sair da roşa, não compensa ficar aqui..." Depois eu saí, eu fiquei 35 anos trabalhando no banco, me aposentei. Eu comecei limpando o chão e me aposentei como gerente. (Fez toda sua carreira no banco.) Não fiz o que eu queria não. Eu era muito ambicioso e a minha vontade era chegar a diretor, sempre tive esse sonho: "vou chegar: vou chegar, só que antes de eu chegar..." (teve que fazer uma operação) Porque o banco é assim: é pressão do presidente, é pressão do diretor, é pressão do regional, é pressão do cliente, aí vem pressão de todo lado. então você fica entre a cruz e a espada. $E$ você acaba assim, num enfartado. Mas a vida é assim, eu vou dizer para o senhor, se eu fosse mais novo eu voltaria para Itália, eu voltaria para os Estados Unidos, pra Inglaterra ou qualquer lugar.

$\mathrm{O}$ meu filho aqui penou, penou, e foi para os Estados Unidos. Está ralando lá, está trabalhando bastante. Ele estava fazendo dois turnos e meio esses dias. ele já comprou uma casa em Mandaguari, comprou um apartamento em Apucarana e pagou R\$ 135.000,00. Aí começaram a tributar o dinheiro que vinha de lá, que era ganho lá e já tributado lá nos Estados Unidos. Eles começaram a tributar aqui, mais vintee-sete-ponto-não-sei-o-quê. O que os brasileiros fizeram? Eles se reuniram lá, ele pegou, e sabe o que fez: ele tinha mais ou menos uns cem mil dólares guardados para comprar mais alguma coisa aqui, e ele não comprou mais aqui, comprou lá nos Estados Unidos. O senhor acha que ele volta? Eu como pai, penso que ele vai voltar para ficar 
perto de mim? Eu estava lá em Goiás quando eu saí do banco e me aposentei. Eu vim para Londrina, sabe para quê? Para ficar perto da minha família, porque eu andei a vida toda sendo transferido para lá e para cá. Quando eu falei, "bom. agora vou ficar perto da minha família", eu cheguei, não demorou um ano, esse rapaz foi embora. Então, o outro que estava aqui em Londrina, foi para Dourados e está lá, tentando. Ele me falou "pai, esse e o tiltimo cartucho". Agora ele tem a cidadania. Com certeza vai querer ir embora se não der certo lá. Quer dizer, a gente vê uma família formada para quê? Para ficar eu e minha esposa.

* Sidnei Marco Dornelas é missionário scalabriniano e Diretor do Centro de Estudos Migratórios (CEM).

\section{NOTAS}

1 - Agradecemos aos leigos atuantes no Santuário Nossa Senhora Aparecida e do Centro Pastoral do Migrante, em Londrina, que gentilmente colaboraram conosco oferecendo o seu depoimento. Agradecemos também e aos padres Valdecir Molinari, Tranqüilo Lorenzin e, de maneira particular, $\mathrm{Pe}$. Moacir Calza que se esforçou para que pudéssemos fazer os encontros que precisávamos com os familiares de emigrantes, tornando possivel esse trabalho. Os nomes dos entrevistados, para fins dessa publicação, foram mudados.

2 - Informaçōes colhidas junto ao Pe. Antonio Garcia Peres Neto, ex-diretor do Centro de Pastoral do Migrante de Londrina.

3 - Numa pesquisa coordenada pela Profa. Alice Yatiyo Asari, da Universidade Estadual de Londrina (UEL), sobre a execução do Programa Vilas Rurais, pelo Governo do Estado do Paraná, e cujos resultados foram analisados e publicados numa série de artigos na revista Geografia (UEL), fica evidente a perda das referências rurais desse proletariado, sua dependência do subemprego urbano, o esgarçamento e a fragilidade de suas relaçōes sociais, o que compromete qualquer politica pública que almeje um "retorno" destes trabalhadores temporários à vida rural.

4 - A partir de uma série de questionários distribuidos entre os alunos de várias escolas estaduais de Londrina, a Pastoral do Migrante buscou fazer uma sondagem sobre o volume e os destinos dos emigrantes brasileiros oriundos desta regiāo. Muitas escolas alegaram vários motivos para não fazer essa sondagem. Quais seriam os motivos? Não constrangimento dos alunos? Medo de que seus parentes seriam denunciados...? O fato é que, das 76 escolas, a Pastoral recebeu respostas de 24. Mais exatamente, de 3.412 questionários respondidos, levantou-se o número de 4.153 pessoas conhecidas fora do Pais. Os destinos mais apontados foram: Japão, 1009; Portugal, 882; Estados Unidos, 561; Inglaterra, 404; Itália, 381: Espanha, 328. Mesmo que imprecisos, esses resultados já indicam como essa problemática migratória é largamente vivenciada na cidade.

5 - Informações colhidas junto ao Pe. Antonio Garcia Peres Neto, ex-diretor do Centro de Pastoral do Migrante de Londrina. A documentaçāo sobre mais de dez anos de atividade pastoral junto aos migrantes sazonais no norte do Paraná se encontra arquivada no Centro Pastoral de Migrantes, em Londrina.

6 - A Paróquia Nossa Senhora Aparecida, em Londrina, foi elevada a Santuário no ano de 1997.

7 - É preciso não esquecer a festa das naçōes, que a paróquia vem realizando nos últimos anos, envolvendo participantes de todos movimentos paroquiais, por ocasião da celebração da Semana do Migrante, na terceira semana de junho, e coordenada pelo Centro Pastoral. É uma ocasiẫo de congraçamento paroquial em torno das diferentes origens, dos diferentes grupos de migrantes dos quais são originários esses paroquianos.

\section{REFERÊNCIAS BIBLIOGRÁFICAS}

ARAKAKI, Ushi

(2007) Como perpetuar uma classe operária. Travessia - revista do migrante, n. 59 , setembro-dezembro, pp. 11-16.
ASARI, Alice Yatiyo; MUNIZ, Helena M. Cabelo; ROSA, Miriam Dantas

(2002) Programa Vilas Rurais: política pública de fixaçẫo dos trabalhadores no campo? Geografia - revista do Departamento de Geociências da Universidade Estadual de Londrina, n. 1, v. 11, janeiro-julho, p. 100-114.

AZZI, Riolando

(2000) A lgreja e os migrantes: as migrações internas e os novos rumos da obra escalabriniana no Brasil (1951-1988). São Paulo, Paulus.

CEM - CENTRO DE ESTUDOS MIGRATÓRIOS

(1986). Migrações no Brasil: o peregrinar de um povo sem terra. São Paulo, Ed. Paulinas.

EL-KHALIB, Faissal

(1969) Municipios do Paraná. História do Paraná, v. 4, Curitiba, Grafipar.

EQUIPE PASTORAL DOS MIGRANTES DOBRADA/ SANTA ERNESTINA

(1988) Pastoral Migratória, uma presença junto aos sazonais. Travessia - revista do migrante, n. 1 , maio-agosto, p. 36-39.

NAKAGAWA, Kyoko Yanagida

(2007) Crianças e adolescentes envolvidos no movimento dekassegui. Travessia - revista do migrante, n. 59, setembro-dezembro, p. 17-25.

SALES, Teresa

(1995) O Brasil no contexto das novas migrações internacionais. Travessia - revista do migrante, n. 21, janeiroabril, p. 5-8.

KLEINKE, Maria de L. Urban; DESCHAMPS, Marley; MOURA, Rosa

(2000) Movimento migratório no Paraná (1986-91 e 1991-1996): origens e destinos convergentes. $2^{\circ}$ Encontro Nacional de Migração. Belo Horizonte, ABEP, p. 187-228.

SASAKI, Elisa

(2006) "Um olhar sobre os migrantes brasileiros no Japāo". Travessia revista do migrante, n.55, maioagosto, p. 5-10.

SAYAD, Abdelmalek

(1998) A Imigração ou os paradoxos da alteridade. São Paulo, EDUSP.

WESTPHALEN, Cecília; MACHADO, Brasil; BALHANA, Altiva

(1988) Ocupação do Paraná. São Paulo, CEM. 